\title{
Resistant starch and soy protein isolate in instant noodles obtained by conventional and vacuum frying
}

\author{
Amido resistente e isolado proteico de soja na produção de \\ macarrão instantâneo obtido pelo processo de fritura \\ convencional e fritura a vácuo
}

María Gabriela Vernaza $^{1 *}$ (), Yoon Kil Chang ${ }^{2}$

${ }^{1}$ Universidad San Francisco de Quito USFQ, Colegio de Ciencias e Ingeniería - El Politécnico, Quito - Ecuador ${ }^{2}$ Universidade Estadual de Campinas (UNICAMP), Faculdade de Engenharia de Alimentos, Departamento de Tecnologia de Alimentos, Campinas/SP - Brasil

${ }^{*}$ Corresponding Author: María Gabriela Vernaza, Universidad San Francisco de Quito USFQ, Colegio de Ciencias e Ingeniería - El Politécnico, Diego de Robles, s/n, Vía Interoceánica, Quito - Ecuador, e-mail: mgvernaza@usfq.edu.ec

Cite as: Vernaza, M. G., \& Chang, Y. K. (2020). Resistant starch and soy protein isolate in instant noodles obtained by conventional and vacuum frying. Brazilian Journal of Food Technology, 23, e2018239.

https://doi.org/10.1590/1981-6723.23918

\begin{abstract}
Health concerns with the consumption of high-fat products and with respect to the intake of fibre are important for consumers. Vacuum frying process is an alternative frying process that increases the quality of foods. The objective was to develop instant noodles aiming to reduce carbohydrate and fat content by adding soy protein isolate (SPI) and resistant starch (RS3), using conventional and vacuum frying processes. A $2^{2}$ central composite rotational design was used for each type of process, and the formulations were optimized using the Response Surface Methodology. The noodles were characterized with respect to fat absorption, cooking time, final resistant starch content and firmness. The noodles produced at the optimized point were also characterized for their isoflavone content, amino acid profile and by scanning electronic microscopy (SEM). The response surfaces showed that the addition of SPI and RS3 to the formulation resulted in reduced fat absorption and texture. Comparing both frying processes it was found that noodles obtained by vacuum frying absorbed $3 \%$ less fat and were less firm than those produced by conventional frying process. The SEM analysis showed that the noodles obtained by conventional frying had a more porous structure, which allowed an easier fat penetration, whereas those produced by vacuum frying showed a more closed structure with fat impregnated on the surface. Regardless of the process used, it was possible to obtain noodles with improved nutritional value, since they showed high fibre (8\%) and protein (approximately $11 \%$ ) contents, considerable isoflavone content $(8.20 \mathrm{mg} / 100 \mathrm{~g})$ and a complete amino acid profile, due to a significant increase in nearly all the amino acids, especially lysine.
\end{abstract}

Keywords: Deep frying; Fibre; Calorie reduction; Pasta; Fat absorption; Response Surface Methodology. 


\section{Resumo}

Preocupações com o consumo de produtos de alto teor de gordura e também com a ingestão de fibras são importantes para os consumidores. A fritura a vácuo é um processo alternativo que pode aumentar a qualidade de produtos desidratados. O objetivo deste trabalho foi desenvolver um macarrão instantâneo visando à redução tanto da absorção de óleo quanto do teor de carboidratos, por meio da adição de isolado proteico de soja (IPS) e amido resistente (AR3), utilizando os processos de fritura convencional e a vácuo. Para obtenção dos macarrões instantâneos, foram realizados dois delineamentos do tipo Composto Central Rotacional $2^{2}$, um com cada tipo de fritura, otimizando a formulação por intermédio da Metodologia de Superfície de Resposta. Os macarrões foram caracterizados quanto à absorção de gordura, ao tempo de cozimento, ao teor final de amido resistente e à firmeza, e, finalmente, foi escolhida uma formulação ótima. Os macarrões produzidos no ponto ótimo foram caracterizados também quanto ao teor de isoflavonas, perfil de aminoácidos e microscopia eletrônica de varredura (MEV). As superfícies de resposta demonstraram que, ao adicionar AR3 e IPS à formulação, a absorção de gordura e os valores de firmeza diminuíram significativamente. Ao comparar os dois processos de fritura, convencional e a vácuo, foi possível observar que os macarrões obtidos pelo processo a vácuo absorveram $3 \%$ a menos de gordura da massa total, contudo apresentaram valores de firmeza menores que os macarrões obtidos pelo processo de fritura convencional. A análise de MEV demonstrou que os macarrões obtidos pelo processo de fritura convencional tiveram uma estrutura mais porosa, deixando a gordura penetrar mais facilmente, enquanto os macarrões obtidos pelo processo a vácuo apresentaram uma estrutura mais fechada, mas com mais gordura impregnada na superfície. Finalmente, foi possível, independentemente do processo utilizado, obter macarrões com melhor valor nutricional, pois eles contiveram alto teor de fibras (aproximadamente 8\%) e proteínas (aproximadamente 11\%), teor considerável de isoflavonas $(8,20 \mathrm{mg} / 100 \mathrm{~g})$ e um perfil mais completo de aminoácidos por causa do aumento significativo de quase todas eles, especialmente de lisina.

Palavras-chave: Fritura por imersão; Fibra; Redução calórica; Macarrão; Absorção de gordura; Metodologia de Superfície de Resposta.

\section{Introduction}

Health concerns with the consumption of high-fat products and with respect to the intake of fibre are important for consumers. In an attempt to increase the consumption of fibre, several alternatives have been proposed, including the development of new products that employ new ingredients that can increase the nutritional and functional value of foods. Resistant starch (RS) is a starch fraction that does not produce glucose in the body since it resists enzymatic digestion in the small intestine, but can be fermented in the colon by bacterial microflora producing mainly gas and short chain fatty acids. Due to this characteristic, resistant starch is usually considered a dietary fibre (Fuentes-Zaragoza et al., 2010). Nowadays, five types of resistant starch (RS1-RS5) have been identified and can be classified according to the nature of the starch, such as the structure of starch granules, cooking and cooling operations and complexation with other components (Remya et al., 2018). RS1 are physically non-accessible starch grains encapsulated in the food matrix, basically because of the cell walls and proteins. Whole or partially ground cereal grains, legumes and other materials containing starch in which the size or composition impede or retard the action of the digestive enzymes, belong to this group. RS2 are native grains, which are highly resistant to digestion by the enzyme $\alpha$-amylase, present especially in green banana, raw potato and high-amylose content starch. RS3is formed after retrograding, due to cooling and ageing of the gel, forming a partially crystalline, insoluble structure that is resistant to enzymatic digestion and different from the initial conformation. It is the most common form and the most important from a technological point of view. RS4is a chemically modified starch (Sajilata et al., 2006). RS5 is formed by complexation of the amylose fraction of starch with lipids, fats and surfactants (Raigond et al., 2015).

The soybean is known as an excellent protein source for human and animal consumption, richer in protein than any other cereal or legume. Soy proteins have a good amino acid balance when compared to other vegetable 
proteins. However, legumes, such as soy, show a reduced amount of the sulfur amino acids and an elevated lysine content. Cereal proteins show the inverse situation with respect to their amino acid composition, and hence the combination of legumes, such as soy, with cereal products made from corn, rice, wheat etc. is advisable, to allow for complementation of the essential amino acids (Delcour \& Hoseney, 2010).

Deep-frying is one of the most common and popular processes used in the food industry and consists of immersing the food in hot oil to remove water. The frying process includes heat and mass transfer between the food and the frying medium causing some changes in the sensory characteristic of food (Saguy \& Dana, 2003). In vacuum frying the food is heated under pressure, reducing the boiling point of the frying oil and the water present in the product, and lowering the presence of oxygen during the frying process which inhibits some reactions such as lipid oxidation and enzymatic browning. Moreover, vacuum frying may help to preserve color and nutrients present in the fried foods (Fan et al., 2005).

The objective of the present work was to develop instant noodles with functional and nutritional properties, aiming to reduce the calorie content by reducing both oil absorption and the digestible carbohydrate content by the addition of soy protein isolate (SPI) and resistant starch type 3 (RS3), using conventional and vacuum frying processes.

\section{Material and methods}

Wheat flour (Bunge, São Paulo, Brazil), Promitor Resistant Starch type III (RS3) (Tate and Lyle, São Paulo, Brazil), Soy Protein Isolate (Solae, São Paulo, Brazil) and Palm Oil (Agropalma, São Paulo, Brazil) were used to develop the noodles.

\subsection{Characterization of raw material}

The quantitative analysis of the isoflavones was carried out following the procedure used by Berhow (2002) using HPLC. The Amino acid composition was determined after $24 \mathrm{~h}$ hydrolysis in $6 \mathrm{M} \mathrm{HCl}$ at $100{ }^{\circ} \mathrm{C}$, the amino acids were reacted with phenylisothiocyanate and the derivatives separated using a Luna $\mathrm{C}-18$, $100 \AA, 5 \mu, 250 \mathrm{~m} \times 4.6 \mathrm{~mm}\left(00 \mathrm{G}-4252\right.$-E0, Torrance, CA, USA) column, at $50{ }^{\circ} \mathrm{C}$. Quantification was carried out by comparison with a standard mixture (Thermo Scientific, Rockford IL, USA) and DL-2aminobutyric acid from Sigma-Aldrich Corp., St. Louis, MO was used as the internal standard. The running time was $24 \mathrm{~min}$. The free amino acids were determined by extracting $1.25 \mathrm{~g}$ flour samples in an $80 \%$ ethanol solution containing $0.1 \mathrm{M} \mathrm{HCl}$ in a $5 \mathrm{~mL}$ volumetric flask and adding $500 \mu \mathrm{L}$ of aminobutyric acid as the internal standard. The mixture was sonicated for $10 \mathrm{~min}$ and homogenized for a further $1 \mathrm{~h}$, followed by centrifugation at $8500 \mathrm{~g}$ for $15 \mathrm{~min}$. The supernatant was filtered through a $0.22 \mathrm{~mm}$ membrane and a $40 \mu \mathrm{L}$ aliquot derivatized as described above, injecting $20 \mu \mathrm{L}$ of the derivatized extract into the HPLC.

\subsection{Experimental design}

Two $2^{2}$ central composite rotational designs (CCRD) were used to study the effects of adding RS3 ( $0-16 \%)$ and SPI (0 to 16\%) in the formulations of instant noodles obtained by conventional and vacuum frying. A total of 12 trials were conducted in each design: 4 for the factorial design, 4 for the axial points and 4 replicates at the central point to estimate error. Finally, an $\alpha= \pm 1.4142$ value was selected to ensure the rotatability of the model (Ribotta et al., 2008). The maximum levels were chosen in preliminary tests, adding as much amounts of resistant starch and soy protein isolate as possible to obtain an adequate dough (sufficiently stretchable and elastic) to produce instant noodles. For noodle production, the methodology described by Vernaza \& Chang (2017) was used.

The instant noodles were characterized for oil absorption (method $\mathrm{n}^{\circ} 30-25.01$, American Association of Cereal Chemists, 2010), moisture content (method $n^{\circ}$ 44-15.01, American Association of Cereal Chemists, 2010) and resistant starch content using the methodology proposed by Goñi et al. (1996). These analyses were determined in four replicates. Firmness was determined in seven replicates using a TA-XT2i texturometer (Stable Micro 
Systems, England) with the $\mathrm{A} / \mathrm{LKB}$ probe (maximum load of $50 \mathrm{~kg}$ ) and with the following conditions: measured in compression force, pre-test and test speed: $0.17 \mathrm{~mm} / \mathrm{s}$; post-test speed: $10 \mathrm{~mm} / \mathrm{s}$; cut distance: $4.7 \mathrm{~mm}$; trigger type: button and trigger force $10 \mathrm{~g}$. For data analysis, the Texture Expert software was used.

\subsection{Determination and characterization of the optimal point}

The optimal point chosen using the experimental designs was processed for each type of frying (conventional and vacuum). The noodles obtained were characterized for their proximate composition, optimal cooking time, resistant starch content in the fried product and after the optimal cooking time (rehydration), isoflavones content, total amino acid content and firmness, according to the methodologies described above. Scanning electronic microscopy (SEM) analyses of the surface and cross-section of the noodles were also carried out with $\mathrm{x} 500$ magnification and x 200 magnification, respectively, in order to compare the internal structure of the noodles produced by the two frying processes. A Scanning Electron Microscope (LEO 440i - Cambridge, UK) was used, where the energy and beam current were $10 \mathrm{kV}$ and $50 \mathrm{~mA}$, respectively. The samples were placed on aluminum supports and covered with a $92 \AA$ gold layer prior the analysis.

\subsection{Data analysis}

When necessary, the results obtained in the characterization of the raw materials and optimal point were statistically analyzed by the Analysis of Variance (ANOVA) and Tukey's test, using the Statistica version 5.0 program (Stat Soft, Inc., Tulsa, USA), with the objective of identifying significant differences $(p \leq 0.05)$ between the samples.

Response Surface Methodology was used to analyze the results obtained from the CCRDs. The statistical calculations were carried out by the standard error using the Statistica version 5.0 software (Stat Soft, Inc., Tulsa, USA).

\section{Results and discussion}

\subsection{Isoflavones content and total amino acid profile of raw material}

Research on soybean isoflavones have shown their protective effect against certain health problems related to menopause, osteoporosis, cancer and cardiovascular diseases (Schmiele et al., 2014). During processing to obtain soybean sub-products, there are changes and losses in the isoflavones originally present in the soybean, nevertheless the total isoflavones content of the soy protein isolate used in this study was $108.10 \mathrm{mg} / 100 \mathrm{~g}$. The concentrations of glycosylated, malonylglycosylated, acetylglycosylated and aglycone forms were $27.8 \%, 33.5 \%, 6.3 \%$ and $32.4 \%$, respectively. Table 1 shows that soy protein isolate had a high percentage (32.4\%) of isoflavones in the aglycone form, due to the fact that during the production of soy protein isolate the glycosylated isomers can be hydrolyzed (Wang \& Murphy, 1996). The physiological properties are predominant when the isoflavones are present in the aglycone form (without glucose) instead of glycosylated (conjugated to glucose) (Ribeiro et al., 2006). Some researchers reported isoflavone contents around $690 \mu \mathrm{g} / \mathrm{g}$ in dried basis in soy protein isolates produced and industrialized in Brazil (Lui, et al., 2003). The concentration of the isoflavone profile of soybean is affected by genetic and environmental factors, as well as by the processing conditions used to obtain products derived from or based on soybean.

Table 2 shows the results obtained for the total amino acid analyses of the wheat flour and SPI. It can be observed that the values obtained for the amino acids of SPI were much higher than those of the wheat flour, since the SPI contains approximately $88 \%$ protein and thus the amino acids are much more concentrated, whereas in the wheat flour they are more diluted. Wheat flour protein presented higher glutamic acid, proline and sulfur amino acid (methionine and cysteine) contents whereas the SPI showed higher values for lysine, arginine and aspartic acid. 
Soy protein is poor in sulfur amino acids, being methionine its limiting amino acid. However, it is rich in lysine, an amino acid deficient in most cereals. Thus, a combination of the proteins from legumes, such as soybean, and from cereals, such as wheat, is advantageous, since they complement each other with respect to methionine and lysine.

Table 1. Determination of isoflavones in raw material and instant noodles.

\begin{tabular}{|c|c|c|c|}
\hline & \multicolumn{3}{|c|}{ Isoflavones (mg/100 g sample) } \\
\hline & SPI & MIcon & MIvac \\
\hline \multicolumn{4}{|l|}{$\beta$-glucosides } \\
\hline Daidzin & $7.31 \pm 0.04$ & $0.52 \pm 0.01$ & $0.45 \pm 0.01$ \\
\hline Glycitin & $1.84 \pm 0.01$ & 0.00 & 0.00 \\
\hline Genistin & $20.91 \pm 0.13$ & $1.67 \pm 0.01$ & $1.50 \pm 0.01$ \\
\hline \multicolumn{4}{|l|}{ Malonylglucosides } \\
\hline Malonyldaidzin & $6.41 \pm 0.03$ & $0.30 \pm 0.01$ & $0.38 \pm 0.00$ \\
\hline Malonylglycitin & $1.44 \pm 0.34$ & $0.10 \pm 0.03$ & $0.20 \pm 0.01$ \\
\hline Malonylgenistin & $28.40 \pm 0.17$ & $1.43 \pm 0.01$ & $1.86 \pm 0.01$ \\
\hline \multicolumn{4}{|l|}{ Acetylglucosides } \\
\hline Acetyldiadzin & $1.07 \pm 0.01$ & $0.16 \pm 0.01$ & $0.05 \pm 0.01$ \\
\hline Acetylglycitin & 0.00 & 0.00 & 0.00 \\
\hline Acetylgenistin & $5.69 \pm 0.02$ & $0.87 \pm 0.00$ & $0.41 \pm 0.01$ \\
\hline \multicolumn{4}{|l|}{ Aglycones } \\
\hline Diadzein & $10.95 \pm 0.00$ & $1.03 \pm 0.00$ & $1.06 \pm 0.00$ \\
\hline Glycitein & $2.63 \pm 0.02$ & $0.22 \pm 0.01$ & $0.25 \pm 0.01$ \\
\hline Genistein & $21.47 \pm 0.01$ & $1.95 \pm 0.01$ & $2.04 \pm 0.01$ \\
\hline Total isoflavones & $108.10 \pm 0.30$ & $8.23 \pm 0.03$ & $8.19 \pm 0.01$ \\
\hline
\end{tabular}

Mean \pm standard deviation of 4 determinations. SPI $=$ soy protein isolate. MIcon $=$ instant noodles obtained by conventional frying. MIvac = instant noodles obtained by vacuum frying.

Table 2. Determination of total amino acids in raw material and instant noodles.

\begin{tabular}{|c|c|c|c|c|c|}
\hline \multirow{2}{*}{ Amino acids ${ }^{1}$} & \multicolumn{5}{|c|}{ Amino acids composition (g/100 g sample) } \\
\hline & SPI & Wheat flour & MIcon & MIvac & Adult Requirement* \\
\hline Histidine & $2.06 \pm 0.00$ & $0.21 \pm 0.02$ & $0.25 \pm 0.00$ & $0.24 \pm 0.00$ & 1,5 \\
\hline Isoleucine & $4.09 \pm 0.00$ & $0.41 \pm 0.00$ & $0.52 \pm 0.01$ & $0.49 \pm 0.00$ & 3,0 \\
\hline Leucine & $7.08 \pm 0.04$ & $0.79 \pm 0.01$ & $0.95 \pm 0.00$ & $0.92 \pm 0.01$ & 5,9 \\
\hline Lysine & $6.11 \pm 0.00$ & $0.25 \pm 0.01$ & $0.48 \pm 0.01$ & $0.48 \pm 0.01$ & 4,5 \\
\hline Methionine & $1.32 \pm 0.00$ & $0.23 \pm 0.01$ & $0.22 \pm 0.00$ & $0.21 \pm 0.00$ & 16 \\
\hline Cysteine & $0.58 \pm 0.02$ & $0.12 \pm 0.01$ & $0.10 \pm 0.00$ & $0.10 \pm 0.01$ & 6 \\
\hline Phenylalanine & $4.89 \pm 0.04$ & $0.58 \pm 0.01$ & $0.68 \pm 0.00$ & $0.66 \pm 0.00$ & \multirow{2}{*}{3,8} \\
\hline Tyrosine & $3.36 \pm 0.05$ & $0.39 \pm 0.00$ & $0.46 \pm 0.01$ & $0.43 \pm 0.00$ & \\
\hline Threonine & $3.03 \pm 0.00$ & $0.29 \pm 0.01$ & $0.35 \pm 0.03$ & $0.35 \pm 0.00$ & 2,3 \\
\hline Tryptophan & n.d. & n.d. & n.d. & n.d. & 0,6 \\
\hline Valine & $4.10 \pm 0.02$ & $0.46 \pm 0.01$ & $0.55 \pm 0.00$ & $0.53 \pm 0.01$ & 3,9 \\
\hline Alanine & $3.56 \pm 0.02$ & $0.33 \pm 0.01$ & $0.43 \pm 0.00$ & $0.41 \pm 0.00$ & - \\
\hline Arginine & $6.95 \pm 0.04$ & $0.46 \pm 0.01$ & $0.70 \pm 0.00$ & $0.67 \pm 0.00$ & - \\
\hline Aspártic acid & $9.68 \pm 0.04$ & $0.43 \pm 0.01$ & $0.83 \pm 0.01$ & $0.78 \pm 0.04$ & - \\
\hline Glutamic acid & $15.98 \pm 0.04$ & $3.82 \pm 0.01$ & $3.57 \pm 0.02$ & $3.42 \pm 0.04$ & - \\
\hline Glycine & $3.43 \pm 0.01$ & $0.39 \pm 0.01$ & $0.46 \pm 0.00$ & $0.45 \pm 0.01$ & - \\
\hline Proline & $4.39 \pm 0.01$ & $1.32 \pm 0.00$ & $1.20 \pm 0.01$ & $1.15 \pm 0.00$ & - \\
\hline Serine & $4.29 \pm 0.01$ & $0.53 \pm 0.01$ & $0.61 \pm 0.01$ & $0.59 \pm 0.01$ & - \\
\hline Total & $84.84 \pm 0.18$ & $10.95 \pm 0.11$ & $12.32 \pm 0.06$ & $11.86 \pm 0.13$ & 27,7 \\
\hline Sulfur amino acids & 1.9 & 0.35 & 0.32 & 0.31 & 2,2 \\
\hline Aromatic & 8.25 & 0.97 & 1.14 & 1.09 & 3,8 \\
\hline
\end{tabular}

Mean \pm standard deviation of 4 determinations. SPI = soy protein isolate. MIcon = instant noodles obtained by conventional frying. MIvac $=$ instant noodles obtained by vacuum frying. n.d. $=$ not determined. ${ }^{*} \mathrm{~g} / 100 \mathrm{~g}$ protein $($ Food and Agriculture Organization of the United Nations, 2007). 


\subsection{Characterization of the instant noodles}

Table 3 shows the results obtained for water absorption, cooking, moisture content, fat absorption, resistant starch content and firmness for each type of frying.

\subsection{Water absorption}

The minimum and maximum values obtained for water absorption in the 12 trials were $61.4 \%$ and $74 \%$, respectively. It can be seen that the equation that explain the water absorption was quadratic, the interaction factor was not significant and eliminated after fitting. The analysis of variance showed that the coefficient of determination was 0.99 and the ratio between $\mathrm{F}_{\text {calculated }}$ and $\mathrm{F}_{\text {tabulated }}$ was 107 at $5 \%$ significance level, allowing to obtain the model (Equation 1) and generate the respective response surface (Figure 1). The response surface showed that the water absorption increased significantly when increasing the SPI content. According to the mathematical model (Equation 1), it can be observed that the addition of SPI was the variable most affecting water absorption. The moisture level or added water depends on the protein content and quality, starch content, especially damage starch, flour granulometry and pentosans. If too little water is added, the pasta will be striped and sometimes the laminar surface of the pasta is modified, leaving the pasta fragmented (not smooth). These results obtained weak strips that easily broke during drying due to the presence of noncohesive zones. The addition of too much water causes problems in the lamination process due to excessive gluten development (Hou, 2010).

water absorption $(\%)=66.73-0.53 \times \mathrm{RS}+0.73 \times \mathrm{RS}^{2}+4.53 \times \mathrm{SPI}+0.56 \times \mathrm{SPI}^{2}$ 


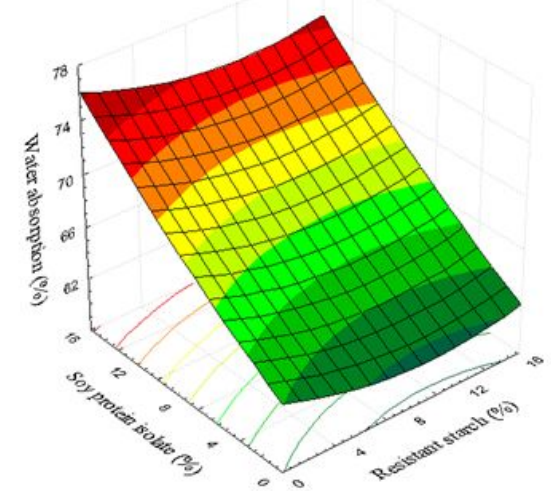

a)

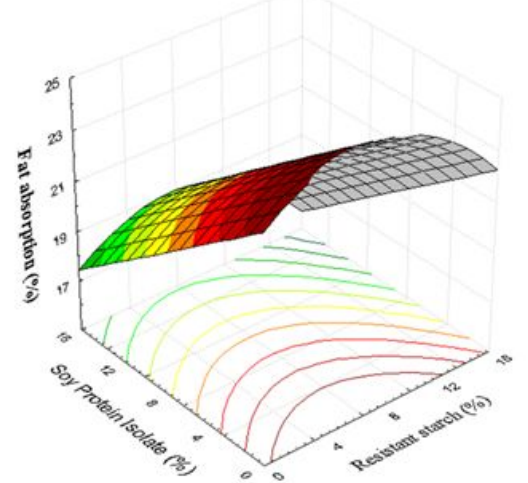

c)

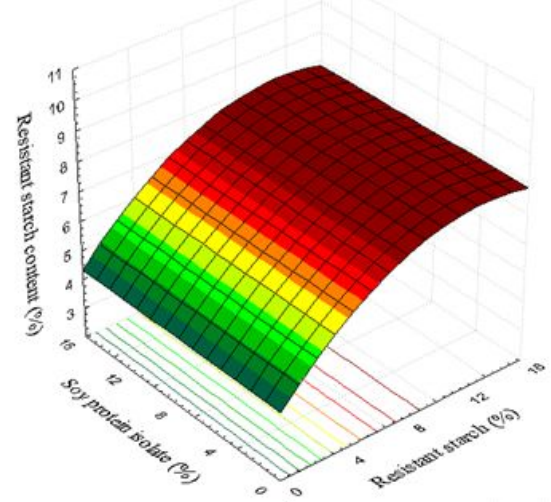

e)

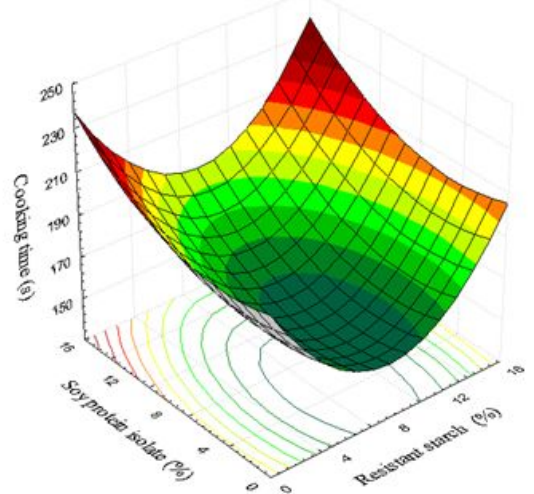

b)

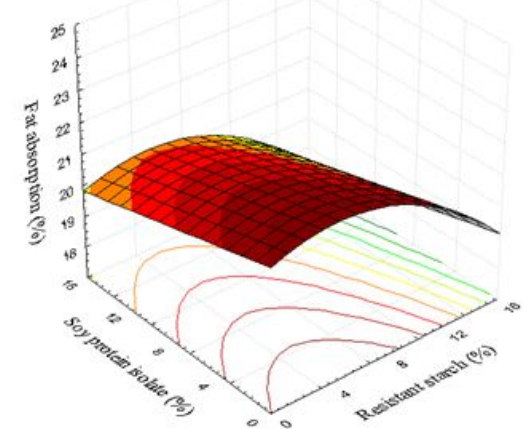

d)

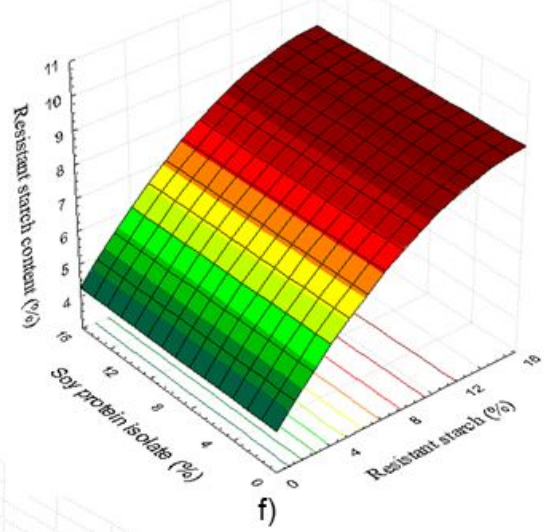

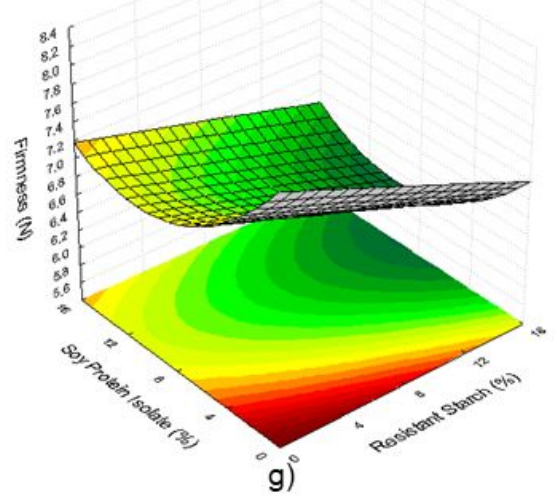

Figure 1. (a) Water absorption; (b) cooking time; (c) FAC; (d) FAV; (e) RSC; (f) RSV; and (g) firmness. 
Table 3. Results obtained by the CCDR.

\begin{tabular}{|c|c|c|c|c|c|c|c|c|}
\hline \multicolumn{9}{|c|}{ Responses } \\
\hline $\begin{array}{l}\text { RS } \\
(\%)\end{array}$ & $\begin{array}{l}\text { SPI } \\
(\%)\end{array}$ & Water abs (\%) & Cooking time (s) & & $\begin{array}{c}\text { Moisture } \\
(\%)\end{array}$ & $\begin{array}{l}\text { Fat } \\
(\%)\end{array}$ & $\begin{array}{l}\text { RS } \\
(\%)\end{array}$ & $\begin{array}{c}\text { Firmness } \\
\text { (N) }\end{array}$ \\
\hline-1 & -1 & 63.50 & 175 & \multirow{12}{*}{ 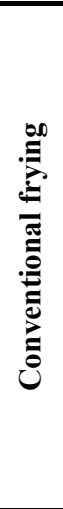 } & $1.46 \pm 0.026$ & $24.42 \pm 0.30$ & $5.85 \pm 0.59$ & $7.54 \pm 0.45$ \\
\hline+1 & -1 & 62.40 & 195 & & $1.70 \pm 0.010$ & $21.88 \pm 0.05$ & $7.29 \pm 0.59$ & $6.74 \pm 0.29$ \\
\hline-1 & +1 & 72.80 & 180 & & $2.18 \pm 0.022$ & $18.24 \pm 0.22$ & $6.57 \pm 0.48$ & $7.25 \pm 0.32$ \\
\hline+1 & +1 & 71.50 & 195 & & $2.00 \pm 0.013$ & $18.28 \pm 0.05$ & $7.96 \pm 0.33$ & $6.65 \pm 0.22$ \\
\hline$-\alpha$ & 0 & 69.10 & 210 & & $2.42 \pm 0.066$ & $20.95 \pm 0.16$ & $3.44 \pm 0.24$ & $6.85 \pm 0.33$ \\
\hline$+\alpha$ & 0 & 67.80 & 205 & & $2.42 \pm 0.015$ & $19.47 \pm 0.12$ & $8.47 \pm 0.83$ & $5.98 \pm 0.36$ \\
\hline 0 & $-\alpha$ & 61.40 & 144 & & $2.13 \pm 0.111$ & $25.09 \pm 0.30$ & $7.01 \pm 0.11$ & $7.65 \pm 0.47$ \\
\hline 0 & $+\alpha$ & 74.00 & 205 & & $2.66 \pm 0.221$ & $19.15 \pm 0.14$ & $7.32 \pm 0.52$ & $6.42 \pm 0.28$ \\
\hline 0 & 0 & 66.80 & 158 & & $2.43 \pm 0.058$ & $22.75 \pm 0.53$ & $7.51 \pm 0.75$ & $6.61 \pm 0.31$ \\
\hline 0 & 0 & 66.60 & 155 & & $1.96 \pm 0.004$ & $21.70 \pm 0.15$ & $7.69 \pm 0.62$ & $6.56 \pm 0.40$ \\
\hline 0 & 0 & 66.70 & 156 & & $2.55 \pm 0.066$ & $22.59 \pm 1.67$ & $7.58 \pm 0.79$ & $6.58 \pm 0.20$ \\
\hline 0 & 0 & 66.80 & 155 & & $2.31 \pm 0.040$ & $22.35 \pm 0.78$ & $7.60 \pm 0.72$ & $6.59 \pm 0.31$ \\
\hline-1 & -1 & & & \multirow{12}{*}{ 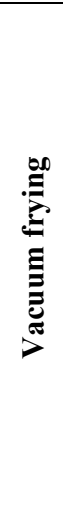 } & $4.82 \pm 0.076$ & $22.26 \pm 0.12$ & $6.07 \pm 0.37$ & $7.30 \pm 0.47$ \\
\hline+1 & -1 & & & & $4.18 \pm 0.009$ & $19.39 \pm 0.04$ & $8.31 \pm 0.93$ & $6.38 \pm 0.37$ \\
\hline-1 & +1 & & & & $6.46 \pm 0.121$ & $20.59 \pm 0.27$ & $5.85 \pm 0.22$ & $6.32 \pm 0.27$ \\
\hline+1 & +1 & & & & $5.68 \pm 0.022$ & $19.34 \pm 0.25$ & $8.26 \pm 0.87$ & $6.12 \pm 0.28$ \\
\hline$-\alpha$ & 0 & & & & $4.83 \pm 0.047$ & $20.25 \pm 0.10$ & $3.61 \pm 0.38$ & $5.65 \pm 0.44$ \\
\hline$+\alpha$ & 0 & & & & $5.08 \pm 0.038$ & $18.08 \pm 0.08$ & $10.12 \pm 0.74$ & $5.31 \pm 0.40$ \\
\hline 0 & $-\alpha$ & & & & $3.82 \pm 0.190$ & $21.43 \pm 0.69$ & $7.63 \pm 0.18$ & $8.44 \pm 0.79$ \\
\hline 0 & $+\alpha$ & & & & $6.11 \pm 0.043$ & $19.17 \pm 0.08$ & $7.58 \pm 0.17$ & $5.31 \pm 0.34$ \\
\hline 0 & 0 & & & & $6.37 \pm 0.040$ & $21.26 \pm 0.33$ & $7.88 \pm 0.74$ & $6.29 \pm 0.19$ \\
\hline 0 & 0 & & & & $5.32 \pm 0.061$ & $21.06 \pm 0.15$ & $8.11 \pm 0.45$ & $6.11 \pm 0.57$ \\
\hline 0 & 0 & & & & $4.71 \pm 0.036$ & $20.84 \pm 0.09$ & $7.94 \pm 0.44$ & $6.30 \pm 0.63$ \\
\hline 0 & 0 & & & & $5.47 \pm 0.050$ & $20.94 \pm 0.19$ & $7.98 \pm 0.21$ & $6.23 \pm 0.46$ \\
\hline
\end{tabular}

$\mathrm{RS}=$ Resistant starch. SPI $=$ Soy protein isolate. $\pm \alpha= \pm 1.4142$.

\subsection{Cooking time}

The same cooking time was used for the noodles obtained using the two frying processes, since there was no significant difference between the samples. The cooking time varied between 144 and $210 \mathrm{~s}$ as the minimum and maximum values, respectively for the 12 trials (Table 3). It can be seen that the Equation 2, which explains the cooking time, was quadratic, the linear factor of resistant starch and the interaction were not significant and hence eliminated after fitting. The analysis of variance showed that the coefficient of determination was 0.81 and the ratio between $\mathrm{F}_{\text {calculated }}$ and $\mathrm{F}_{\text {tabulated }}$ was 3.78 at $5 \%$ significance level, which allow to obtain the mathematical model (Equation 2), and the generation of the respective response surface (Figure 1). The response surface showed that the shortest cooking times were obtained with intermediate levels of resistant starch and intermediate to low levels of soy protein isolate (below 8\%). Also, cooking time increased significantly when increasing the RS3 and SPI contents. This increase can be explained by the fact that the particles of SPI and of RS3 took longer to hydrate, leaving the noodles with a raw appearance when not completely hydrated.

Cooking time $(\mathrm{s})=156+24.56 \times \mathrm{RS}^{2}+11.41 \times \mathrm{SPI}+8.06 \times \mathrm{SPI}^{2}$

\subsection{Moisture content and fat absorption}

A response surface could not be generated for the response of moisture content, since the data obtained (Table 3) were extremely close to each other for both conventional and vacuum frying. It is important to maintain the moisture content below $10 \%$ in the samples to avoid microbial growth and maintain a longer product shelf life. Drying by frying is a very fast process. Water vaporizes quickly from the surface of the 
noodles upon dipping into the hot oil. Dehydration of the exterior surface drives water to migrate from the interior to the exterior of the noodle strands. Eventually, some of the water in the noodles is replaced by oil. Many tiny holes are created during the frying process due to the mass transfer, and they serve as channels for water to get in upon rehydration in hot water (Hou, 2010). Therefore, the shelf life of instant noodles is related also with the fat content and fat degradation. Because of the dehydration process (frying) the water activity of instant noodles could be in the range of 0.3 , which is a stable range that avoid microbial growth.

Fat absorption during frying is important from both the economic and nutritional points of view. Fat absorption increases production costs and decreases the product shelf life due to the rancidity of the oil absorbed by noodles (Wu et al., 2006). The values for fat absorption obtained using conventional frying (FAC) varied from $18.08 \%$ to $25.09 \%$ and for vacuum frying (FAV) varied from $18.28 \%$ to $22.2 \%$ (minimum and maximum values, respectively) for the 12 trials. It can be seen that the equations that explain the fat absorption of noodles obtained by conventional (Equation 3) and vacuum frying (Equation 4) was quadratic, and the quadratic factor of SPI and the interaction factor were not significant and were eliminated after fitting. The analysis of variance for the conventional process showed that the coefficient of determination was 0.95 and the ratio between $\mathrm{F}_{\text {calculated }}$ and $\mathrm{F}_{\text {tabulated }}$ was 12.4 at $5 \%$ significance level; for vacuum frying the analysis of variance showed that the coefficient of determination was 0.84 and the ratio between $F_{\text {calculated }}$ and $F_{\text {tabulated }}$ was 4 at the $5 \%$ level of significance, which allow to obtain the mathematical models (Equation 3 and Equation 4) and allow the generation of the respective response surfaces (Figure 1).

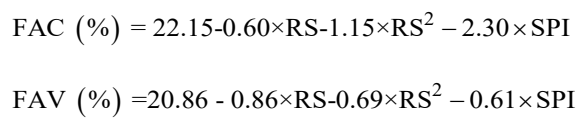

The analysis of the two models obtained showed the same tendency. On analyzing the regression coefficients of the mathematical models, a negative influence of the variables on fat absorption can be seen, such that on adding resistant starch or soy protein isolate, the fat content decreased. Thus, the lowest fat absorption values could be obtained with the highest values of these two variables.

Table 3 shows the results obtained by conventional and vacuum frying for fat absorption. The difference between both processes was not as high as expected. Other authors reported a reduction of up to $45 \%$ in fat absorption using vacuum frying process (Garayo \& Moreira, 2002; Mariscal \& Bouchon, 2008; Dueik, et al., 2010). Several authors explained the mechanism of fat absorption in vacuum-fried technology (Garayo \& Moreira, 2002; Fan et al., 2005; Troncoso et al., 2006). Troncoso et al. (2006) explained that it is necessary to have a de-oiling mechanism to reduce fat absorption of vacuum-fried products and they explained that the increase in fat content after vacuum frying can be characterized mainly by two steps: i) the frying period; and ii) the pressurization period. In vacuum frying, the heat and mass transfer rates are high due to a decrease in the boiling point of the water. In the first stage, the high rate of mass and heat transfer produces partial evaporation of the water in the food, which moves from the inside of the product to the oil medium, and is partially replaced by oil. In the second stage (pressurization), which proceeds after the product has been removed from the oil but is still inside the vessel at the frying pressure and temperature, there is a rapid increase in pressure in the pores, causing the oil adherence to the surface of the product to penetrate into the food, generating a sponge effect, until the pressure at the pores matches the atmospheric pressure.

\subsection{Final resistant starch content}

After conventional frying, the values for final resistant starch (RSC) varied between $4.44 \%$ and $8.47 \%$ as the minimum and maximum values, for the 12 trials. The analysis of variance showed that the coefficient of determination was 0.85 and the ratio between $\mathrm{F}_{\text {calculated }}$ and $\mathrm{F}_{\text {tabulated }}$ was 6.2 at $5 \%$ significance level, which allow to obtain the mathematical model (Equation 5) and allow the generation of the respective response surface (Figure 1). 
After vacuum frying, the final values for resistant starch (RSV) varied between 4.61 and $10.12 \%$ as the minimum and maximum values for the 12 trials. It can be seen that the equation that explains the final resistant starch content was quadratic and was represented solely by the effects of the variable of resistant starch. The analysis of variance showed that the coefficient of determination was 0.89 and the ratio between $\mathrm{F}_{\text {calculated }}$ and $\mathrm{F}_{\text {tabulated }}$ was 10 at 5\% significance level, which allow to obtain the mathematical model (Equation 6) and allow the generation of the respective response surface (Figure 1). Soy protein isolate had no effect on the residual resistant starch content after the two frying processes used. Vernaza \& Chang (2017) reported around 30\% loss of resistant starch type II in noodles with addition of green banana flour while the loss was around $18 \%$ in noodles with addition of resistant starch type III.

$$
\begin{aligned}
& \operatorname{RSC}(\%)=7.44+1.07 \times \mathrm{RS}-0.51 \times \mathrm{RS}^{2} \\
& \operatorname{RSV}(\%)=7.81+1.73 \times \mathrm{RS}-0.54 \times \mathrm{RS}^{2}
\end{aligned}
$$

\subsection{Firmness}

The values for firmness of the noodles obtained by conventional frying varied between $5.98 \mathrm{~N}$ and $7.65 \mathrm{~N}$ as the minimum and maximum values, respectively, for the 12 trials. It can be seen that the equation that explain the firmness was quadratic, but the quadratic factor for resistant starch and the interaction factor were not significant and were eliminated after fitting. The analysis of variance showed that the coefficient of determination was 0.83 and the ratio between $F_{\text {calculated and }} F_{\text {tabulated }}$ was 3 at $10 \%$ significance level, which allow to obtain the mathematical model (Equation 7) and allow the generation of the respective response surface (Figure 1).

Firmness $(\mathrm{N})=6.58-0.33 \times \mathrm{RS}-0.26 \times \mathrm{SPI}+0.31 \mathrm{SPI}^{2}$

The values for texture of the noodles obtained by vacuum frying varied between $5.3 \mathrm{~N}$ and $8.4 \mathrm{~N}$ as the minimum and maximum values, respectively, for the 12 trials. However, response surfaces and a mathematical model could not be generated, since an analysis of the effects showed that the only parameters with a significant effect $(p<0.10)$ were the linear and the quadratic effects for soy protein isolate. Thus, the mathematical model and response surface were not considered, since, on ignoring the non-significant effects, the coefficient of determination $\left(\mathrm{R}^{2}\right)$ showed a low, non-significant value $(0.68)$.

From the results obtained, it can be concluded that the addition of other ingredients to the formulation of instant noodles can affect the texture, independently of the process used. Wheat flour contains unique proteins, gliadins and glutenins with hydration and mechanical energy form gluten. The use of wheat flour in the production of various products is mainly influenced by the quantity and quality of the gluten, more than by the other ingredients. Thus, the addition of any other ingredient that is not a constituent of wheat or gluten, will significantly alter the rheological characteristics of the mass. It can be seen that the addition of RS3 and SPI diluted the gluten network forming proteins (gliadin and glutenin), favoring the formation of a weaker dough structure, resulting in noodles that were less firm.

\subsection{Characterization of the optimal points}

After analyzing the results, mainly fat absorption and resistant starch content, the formulation with the addition of $12 \%$ resistant starch (RS) and $8 \%$ soy protein isolate (SPI) was chosen and tested with the two frying processes, since it was found to guarantee a medium fat absorption with high resistant starch content.

The only component showing significant differences in the proximate composition was the fat content (Table 4). With vacuum frying, the total fat content of the noodles was reduced by $3 \%$. The consumption of instant noodles has been increasing considerably in Brazil, mostly consumed by adolescents and children. The addition of $8 \%$ SPI resulted in a product of important source of protein. In addition, there was an increase in the isoflavone content (Table 1), differentiating this product from the traditional ones found on the market. 
The histology of the samples could be analyzed with the aid of the images obtained by scanning electronic microscopy (Figure 2). The surfaces and cross-sections of the noodles obtained by the two frying processes were analyzed by electronic microscopic. In the microscopic images, the fat is the whitish layer covering the noodles. In the surface views (Figure 2a), it can be observed that the noodles obtained by vacuum frying had a greater fat content on the surface than those obtained by conventional frying. On the other hand, the images of the cross-sections (Figure $2 b$ ) showed that the vacuum fried noodles had a more closed structure, whereas those obtained by conventional frying had a more porous structure.
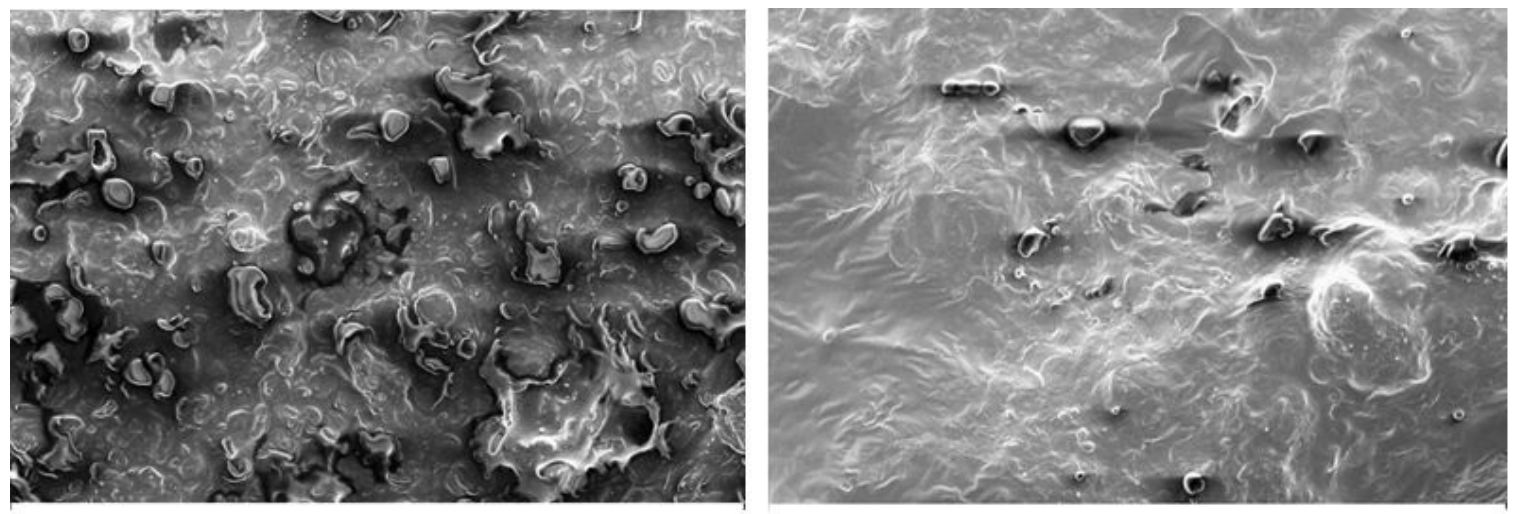

a)
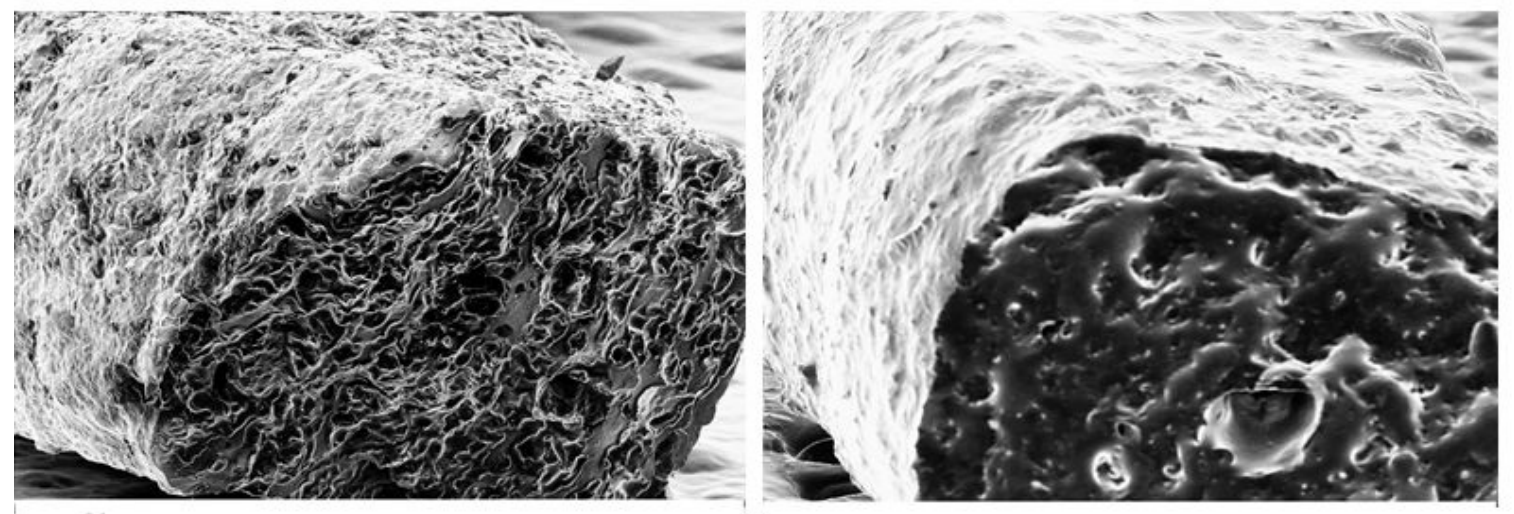

b)

Figure 2. (a) Scanning electronic microscopy images of the surfaces of the noodles obtained by conventional (left) and vacuum (right) frying with x 500 magnification; (b) Scanning electronic microscopy images of the cross-sections of the noodles obtained by conventional (left) and vacuum (right) frying with x 200 magnification

The instant noodles on sale nowadays are produced from wheat flour, salt and in some cases very low proportions of guar gum, showing no health benefit. However, in this study, in addition to these raw materials, soy protein isolate and resistant starch were added. Table 1 shows that the final product obtained in this study contained approximately $8 \mathrm{mg}$ isoflavones per $100 \mathrm{~g}$ product, since in the vacuum frying process, the isoflavones were not degraded. If the instant noodles had been produced solely with wheat flour, the total amino acid contents would have been smaller. Table 2 shows the comparison of the total amino acid contents found for the wheat flour with those obtained for the instant noodles. It can be seen that the majority of the amino acids increased significantly with the exception of the sulfur amino acids glutamic acid and proline. This can be explained by the fact that soy protein isolate contains low contents of these amino acids, diluting those found in the wheat flour. It is important to mention that the lysine content doubled in the final product, and thus, it can be concluded that the addition of soy protein isolate increased the nutritive value of the instant 
noodles, since the combination of the proteins from legumes and cereals are complementary in relation to lysine. Other amino acids that increased considerably were aspartic acid and arginine.

The resistant starch content was also analyzed in the cooked, ready-to-eat samples, that is, after cooking for $170 \mathrm{~s}$ in boiling water. The values obtained were $6.11 \pm 0.47 \%$ and $7.04 \pm 0.81 \%$ for the noodles fried under atmospheric pressure and under vacuum, respectively. The percent loss of resistant starch, during cooking (rehydration), of the samples was approximately $12 \%$. Despite the loss during rehydration, the instant noodles obtained by both processes presented resistant starch contents above $6 \%$.

Moreover, the experimental value of each of the response was compared with those predicted by the equations of the model (Table 5). When comparing the experimental values with those predicted by the obtained equations, we observe in Table 5 that the deviations were relatively low $(<10 \%)$, validating the mathematical models obtained in this study.

Table 4. Proximate composition of the optimal points.

\begin{tabular}{ccc}
\hline Component (\%) & MIcon & MIvac \\
\hline Moisture* $^{*}$ & $2.17 \pm 0.041^{\mathrm{a}}$ & $2.22 \pm 0.060^{\mathrm{a}}$ \\
\hline Fat $^{*}$ & $23.40 \pm 0.113^{\mathrm{a}}$ & $20.28 \pm 0.015^{\mathrm{b}}$ \\
\hline Proteins* $^{*}$ & $11.66 \pm 0.526^{\mathrm{a}}$ & $11.31 \pm 0.082^{\mathrm{a}}$ \\
\hline Ash* $^{\mathrm{a}}$ & $1.70 \pm 0.010^{\mathrm{a}}$ & 64.54 \\
\hline Carbohydrates** & 60.97 & $8.43 \pm 0.06^{\mathrm{a}}$ \\
\hline Total dietary fiber* & $8.13 \pm 0.79^{\mathrm{a}}$ & 0.05 \\
\hline
\end{tabular}

* Mean of 3 determinations. MIcon = instant noodles obtained by conventional frying. MIvac = instant noodles obtained by vacuum frying.

**Calculated by difference, includes the dietary fiber fraction. Means with different letters in the same line show significant statistical differences between the samples by Tukey's test $(p<0.05)$.

Table 5. Predicted and Experimental values obtained in the models validation.

\begin{tabular}{cccc}
\hline Parameter & $\begin{array}{c}\text { Experimental } \\
\text { value }\end{array}$ & $\begin{array}{c}\text { Predicted } \\
\text { value }\end{array}$ & $\begin{array}{c}\text { Relative } \\
\text { deviation (\%) }\end{array}$ \\
\hline Water absorption (\%)* & 66.60 & 66.72 & -0.8 \\
\hline Cooking time (s)* & 170 & 168.3 & 1.01 \\
\hline Fat absorption (\%) (conventional frying - FAC)* & $22.33 \pm 0.113$ & 21.15 & 5.58 \\
\hline Fat absorption (\%) (vacuum frying - FAV) & $20.14 \pm 0.015$ & 19.90 & 1.21 \\
\hline $\begin{array}{c}\text { Final resistant starch content (\%) (conventional } \\
\text { frying - RSC)** }\end{array}$ & $6.95 \pm 0.59$ & 7.94 & 9.47 \\
\hline $\begin{array}{c}\text { Final resistant starch content (\%) (vacuum frying - } \\
\text { RSV)** }\end{array}$ & $7.89 \pm 0.79$ & 8.62 & 8.47 \\
\hline Firmness (N) (conventional frying)*** & $63.11 \pm 3.96$ & 60.98 & 3.49 \\
\hline Firmness (N) (vacuum frying)*** & $61.06 \pm 2.60$ & - & - \\
\hline
\end{tabular}

*Arithmetic means of three replicates. ${ }^{* *}$ Arithmetic means of four replicates. ${ }^{* * *}$ Arithmetic means of seven replicates.

\section{Conclusions}

Fat absorption was reduced because of the addition of soy protein isolate (SPI) and resistant starch (RS3) during the atmospheric and vacuum frying process. However, higher fat content and firmer noodles were obtained with atmospheric frying. On the other hand, noodles obtained by vacuum frying showed less fat content. Thus, with the help of the mathematical models and the response surfaces, it can be concluded that the addition of SPI and RS3 affected the texture (firmness) of the noodles due to dilution of the glutenforming proteins, resulting in less firm noodles. In the characterization of the noodles obtained at the optimal point (12\% RS3 and $8 \%$ SPI), the noodles obtained by vacuum frying presented approximately $3 \%$ less fat in the total mass. The noodles obtained by both processes presented considerable protein contents (about $15 \%$ on a dw and defatted basis) and high fibre contents. The addition of SPI allowed to obtain instant noodles with considerable isoflavone contents and to increase the contents of all the amino acids except the sulfur ones. Finally, independently of the frying process used, it was possible to develop a new formulation of 
noodles, with better nutritional properties because of the high fibre and protein contents, the presence of isoflavones and an improved amino acid profile.

\section{Acknowledgements}

The authors thank FAPESP (Process number 08/02474-1) for the grant provided for this study and Bunge, Tate and Lyle and Agropalma, for their donations.

\section{References}

American Association of Cereal Chemists - AACC. (2010) Approved methods of the American Association of Cereal Chemists. St. Paul: AACC International. Retrieved in 2017, August 4, from http://methods.aaccnet.org/toc.aspx

Berhow, M. A. (2002). Modern analytical techniques for flavonoid determination. In B. Buslig \& J. Manthey (Eds.), Advances in experimental medicine and biology (pp. 61-76). New York: Klusher Academic.

Delcour, J., \& Hoseney, C. (2010). Principles of cereal science and technology (3rd ed., 270 p.). St. Paul: AACC International. http://dx.doi.org/10.1094/9781891127632.

Dueik, V., Robert, P., \& Bouchon, P. (2010). Vacuum frying reduces oil uptake and improves the quality parameters of carrot crisps. Food Chemistry, 119(3), 1143-1149. http://dx.doi.org/10.1016/j.foodchem.2009.08.027

Fan, L. P., Zhang, M., Xiao, G. N., Sun, J., \& Tao, Q. (2005). The optimization of vacuum frying to dehydrate carrot chips. International Journal of Food Science \& Technology, 40(9), 11-919. http://dx.doi.org/10.1111/j.1365-2621.2005.00985.x

Food and Agriculture Organization of the United Nations - FAO. World Health Organization - WHO. United Nations University UNU. (2007). Protein and amino acid requirements in human nutrition: Report of a joint FAO/WHO/UNU expert consultation. Geneva: WHO. Retrieved in 2018, March 21, from http://www.who.int/iris/handle/10665/43411

Fuentes-Zaragoza, E., Riquelme-Navarrete, M. J., Sanchez-Zapata, E., \& Perez-Alvarez, J. A. (2010). Resistant starch as a functional ingredient: A review. Food Research International, 43(4), 931-942. http://dx.doi.org/10.1016/j.foodres.2010.02.004

Garayo, J., \& Moreira, R. (2002). Vacuum frying of potato chips. Journal of Food Engineering, 55(2), 181-191. http://dx.doi.org/10.1016/S0260-8774(02)00062-6

Goñi, I., García-Diz, L., Mañas, E., \& Saura-Calixto, F. (1996). Analysis of resistant starch: A method for foods and food products. Food Chemistry, 56(4), 445-449. http://dx.doi.org/10.1016/0308-8146(95)00222-7

Hou, G. (2010). Asian noodles: Science, technology, and processing (1. ed., 439 p.). New York: Wiley. http://dx.doi.org/10.1002/9780470634370.

Lui, M. C., Aguiar, C. L., Alencar, S., Scamparini, A., \& Park, Y. K. (2003). Isoflavonas em isolados e concentrados proteicos de soja. Food Science and Technology, 23, 206-212. http://dx.doi.org/10.1590/S0101-20612003000400038

Mariscal, M., \& Bouchon, P. (2008). Comparison between atmospheric and vacuum frying of apple slices. Food Chemistry, 107(4), 1561-1569. http://dx.doi.org/10.1016/j.foodchem.2007.09.031

Raigond, P., Ezekiel, R., \& Raigond, B. (2015). Resistant starch in food: A review. Journal of the Science of Food and Agriculture, 95(10), 1968-1978. PMid:25331334. http://dx.doi.org/10.1002/jsfa.6966

Remya, R., Jyothi, A. N., \& Sreekumar, J. (2018). Effect of chemical modification with citric acid on the physicochemical properties and resistant starch formation in different starches. Carbohydrate Polymers, 202, 29-38. PMid:30287003. http://dx.doi.org/10.1016/j.carbpol.2018.08.128

Ribeiro, M. L., Mandarino, J. M. G., Carrao-Panizzi, M. C., Oliveira, M. C. N., Campo, C. B. H., Nepomuceno, A. L., \& Ida, E. I. (2006). $\beta$-glucosidase activity and isoflavone content in germinated soybean radicles and cotyledons. Journal of Food Biochemistry, 30(4), 453-465. http://dx.doi.org/10.1111/j.1745-4514.2006.00075.x

Ribotta, P., Pérez, G., Añón, M., \& León, A. (2008). Optimization of additive combination for improved soy-wheat bread quality. Food and Bioprocess Technology, 3(3), 395-405. http://dx.doi.org/10.1007/s11947-008-0080-z

Saguy, I. S., \& Dana, D. (2003). Integrated approach to deep fat frying: Engineering, nutrition, health and consumer aspects. Journal of Food Engineering, 56(2-3), 143-152. http://dx.doi.org/10.1016/S0260-8774(02)00243-1

Sajilata, M. G., Singhal, R. S., \& Kulkarni, P. R. (2006). Resistant starch: A review. Comprehensive Reviews in Food Science and Food Safety, 59(1), 1-17. http://dx.doi.org/10.1111/j.1541-4337.2006.tb00076.x

Schmiele, M., Vernaza, M. G., Paucar-Menacho, M. L., \& Chang, Y. K. (2014). Soybean: Bioactive compounds improved by germination, fermentation and enzymatic hydrolysis. In R. Mora-Escobedo, J. Berrios \& G. F. Gutierrez-Lopez (Eds.), Food science and technology: Seed as functional foods and nutraceutical (pp. 3-22). New York: Nova Publicher.

Troncoso, E., Pedreschi, F., \& Zuniga, R. N. (2006). Comparative study of physical and sensory properties of pre-treated potato slices during vacuum and atmospheric frying. Lebensmittel-Wissenschaft + Technologie, 42(1), 187-195. http://dx.doi.org/10.1016/j.Iwt.2008.05.013

Vernaza, M. G., \& Chang, Y. K. (2017). Survival of resistant starch during the processing of atmospheric and vacuum fried instant noodles. Food Science and Technology, 37(3), 425-431. http://dx.doi.org/10.1590/1678-457x.17716 
Wang, H. J., \& Murphy, P. A. (1996). Mass balance study of isoflavone during soybean processing. Journal of Agricultural and Food Chemistry, 44(8), 2377-2383. http://dx.doi.org/10.1021/jf950535p

Wu, J., Aluko, R. E., \& Corke, H. (2006). Partial least-squares regression study of the effect of wheat flour composition, protein and starch quality characteristics on oil content of steamed-and-fried in-stant noodles. Journal of Cereal Science, 44(2), 117126. http://dx.doi.org/10.1016/j.jcs.2006.05.008 